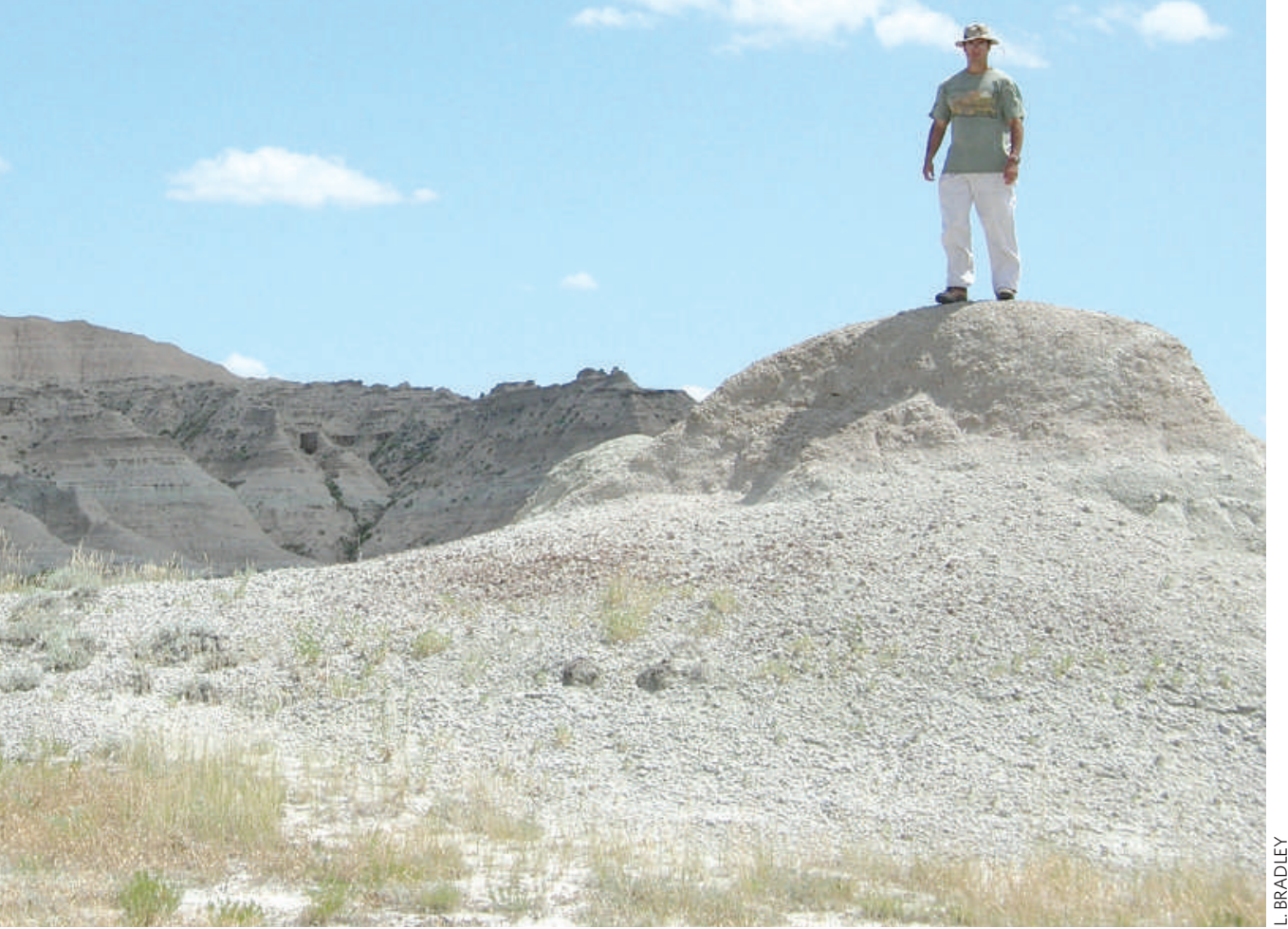

Lawrence Bradley's campaign for tribal involvement has helped to revamp plans for managing Badlands National Park in South Dakota.

agreement with the reservation's Oglala Sioux under which tribal members are consulted about the fate of fossils found on their lands. But it was deemed to be insufficient, so discussions have begun with a view to including fossil discoveries in the park's new 20-year plan, says Rachel Benton, a palaeontologist with the park service. As geological formations there date to about 50 million years ago, the primary impact would be largely on mammal fossils, Benton says.

Although there was many a furrowed brow to be seen in front of Bradley's poster — which referred to "grave desecration" by pioneering scientific explorers - some palaeontologists saw advantages in his proposals. One such idea was to create tribal museums, where fossils from Native American lands could be displayed.

"It would be a great idea for teaching natural history to kids," says Lawrence Flynn, an assistant director at Harvard University's Peabody Museum of Archaeology and Ethnology in Cambridge, Massachusetts.

Daniel Chaney, a palaeobiologist at the National Museum of Natural History in Washington DC, recalled that as a youth he worked with renowned collectors for the American Museum who would consult with tribal councils, often in the tribe's native language. "They always went to the landowner," Chaney says. Rex Dalton dais". He suggested that Buse be warned to stop, "with the punishment being that we will complain up his academic line". He added that a lawsuit could be "reserved for a later approach".

Yamada replied: "I think that there are two courses of action. One is to sue him for knowingly defaming our product even after we have set him straight as to the facts. The other is to launch a well-planned offensive on behalf of Avandia." Yamada recommended the latter.

In an interview with Nature last week, Yamada said that after receiving Claypool's e-mail he called Buse's boss "to be certain that he was a legitimate academic". He said that he was reassured to learn that Buse was "a qualified scientist making the best of the data that he had". A careful reading of the e-mails released by Grassley, Yamada added, shows that "I did not initiate any discussion of a lawsuit [against Buse]". He added: "Nor did I ever discuss a lawsuit with anybody else ... I wouldn't want the media to think it's some diabolical plot hatched by me against $\mathrm{Dr}$ Buse, because nothing could be further from the truth."

"I don't think that Dr Yamada is the bad guy in this story," Buse says. "He did his job and he did it in a fairly sensitive way." He adds that he didn't have a problem, then or now, with Yamada calling his chairman to check his credentials. "That wasn't the disturbing bit. The most disturbing part was the veiled threat of a lawsuit."

Buse said that the threat came from one of many other company officials who deluged him with phone calls - prompting him to write to Yamada, asking him to "call off the dogs".

Meredith Wadman

1. Nissen, S. E. \& Wolski, K. N. Engl. J. Med. 356, 2457-2471 (2007)

2. Singh, S. et al. J. Am. Med. Assoc. 298, 1189-1195 (2007).

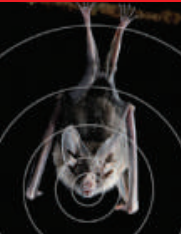

ANCIENT BAT FLEW WITHOUT ECHOLOCATION

Researchers scrounge to get

their hands on samples of 20-clawed bat.

www.nature.com/news

\section{Air permit blocks Kansas coal plants}

Sunflower Electric Power Corporation had the documents in order for its plans to build a pair of 700-megawatt coal-fired power plants in Kansas, and all of the technical requirements had been met. A key state official acknowledged this last week, but refused to grant the company an air-quality permit because of concerns about global warming.

The Sunflower ruling marks the first time in the United States that powerplant plans have been halted over fears that carbon-dioxide emissions endanger people and the environment.

The decision by Roderick Bremby, Kansas secretary for health and the environment, was based in part on an April Supreme Court ruling that the US Environmental Protection Agency (EPA) has the authority to regulate carbon dioxide in automobile emissions (see Nature 446, 589; 2007) - and, by extension many argue, from power plants. "The secretary believes it would be irresponsible to ignore the information about the effects of carbon dioxide and greenhouse gases," says Joe Blubaugh, spokesman for the Kansas Department of Health and Environment. Sunflower blasted the decision and promised to pursue "legal and legislative remedies".

"It's a political decision," says Frank Maisano, an energy-industry lobbyist with Bracewell \& Giuliani based in Washington DC. But Mark Brownstein, who handles business partnerships for green campaigner Environmental Defense, says the move is a logical extension of the Supreme Court decision.

Meanwhile, California is expected to begin proceedings to sue the EPA this week in an effort to allow the state to set its own greenhouse-gas emissions standards for automobiles. Jeff Tollefson

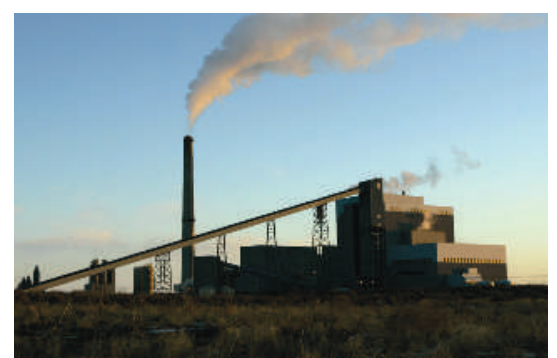

Sunflower Electric has been denied permission to build new coal-powered plants. 